\title{
Associations of high and low milk protein concentrations with energy allocation, milk production, and concentrations of blood plasma metabolites and hormones in Holstein-Friesian cows
}

\author{
M. L. Douglas, ${ }^{*} \dagger^{1}$ L. C. Marett, ${ }^{*}$ K. L. Macmillan, $\dagger$ J. M. Morton, $\ddagger$ M. C. Hannah, ${ }^{*}$ A. D. Fisher, $\dagger$ \\ and M. J. Auldist* \\ ${ }^{*}$ Agriculture Research, Department of Economic Development, Jobs, Transport and Resources, Ellinbank, Victoria 3821, Australia \\ †Faculty of Veterinary and Agricultural Sciences, The University of Melbourne, Werribee, Victoria 3030, Australia \\ ‡Jemora Pty Ltd., Geelong, Victoria 3220, Australia
}

\begin{abstract}
A positive association between milk protein concentration (MPC) and reproductive performance in dairy cows has been shown in several studies globally. This association may positively influence farm productivity and profitability, particularly in seasonally calving, pasture-based herds. However, the differences in milk production and energy allocation, physical characteristics, and blood plasma nutrient status between cows with differing MPC have not been examined, and the underlying mechanisms responsible for the association remain undefined. The objective of this study was to examine associations between MPC and nutrient partitioning in primiparous Holstein-Friesian cows managed under pasture-based dairying conditions, and to identify differences that may indicate the underlying mechanisms. Data were collected from 85 cows at regular intervals during the early part of the 2013 to 2014 seasonal lactation, including daily milk yield, weekly milk composition, weekly body condition score measurements, as well as weekly blood plasma metabolite and hormone concentrations. Cows were retrospectively separated into quartiles based on their average MPC during the first $120 \mathrm{~d}$ of lactation, and comparisons were made between cows within the highest (high; 3.22 to $3.40 \%$ ) and the lowest (low; 2.87 to $3.00 \%)$ MPC quartiles. The high-MPC cows had lower daily milk yields, yet did not differ in the daily yields of milk solids (protein + fat) compared with the lowMPC cows. After parturition, the high-MPC cows had greater blood plasma concentrations of glucose, insulin, insulin-like growth factor-1 and leptin compared with the low-MPC cows and maintained their body condition score, despite no differences in these variables prepar-
\end{abstract}

Received May 1, 2016.

Accepted August 9, 2016.

${ }^{1}$ Corresponding author: meaghan.douglas@ecodev.vic.gov.au tum. These results indicate an increased partitioning of nutrients toward milk synthesis at the expense of body condition for cows in the low MPC quartile. However, average daily energy outputs in milk were similar in the high- and low-MPC cows. The high-MPC cows calved $12 \mathrm{~d}$ earlier in the seasonal calving period, reflecting superior reproductive performance when cows in this quartile were $15 \mathrm{mo}$ of age. These results suggest that at least part, but not all, of the reported associations between MPC and dairy cow fertility are related to nutrient status during early lactation. Further research is required to understand and use the association.

Key words: reproductive performance, energy allocation

\section{INTRODUCTION}

The well-documented decline in the fertility of dairy cattle in many countries over several decades has generally been associated with increased milk yield and an increase in the proportion of genes derived from Holstein-Friesian sires of North American origin (Buckley et al., 2003; Butler, 2003). Seasonally concentrated calving patterns found in the pasture-based dairy industries of Australia, New Zealand, and Ireland optimize pasture utilization and enhance profitability in low-cost production systems. In these systems, declining reproductive performance is exacerbated by the need to breed cows when they are at peak milk yield less than 12 wk after calving and gradually recovering from negative energy balance (NEB). Many herd owners have difficulty maintaining the 12-mo annual calving interval essential to seasonally concentrated calving patterns, and the cow wastage that results from culling cows that fail to conceive in time is a substantial cost (Auldist et al., 2007; Morton, 2011).

Two studies conducted mainly in Victoria, Australia, showed that one of the factors having the strongest association with the probability of conception within 
6 wk following the start of a seasonal breeding program was a cow's milk protein concentration (MPC; Morton, 2000, 2011). This positive association between MPC and dairy cow fertility has also been shown in New Zealand (Xu and Burton, 1996), but it is strongest in cows in the pasture-based production systems of southeastern Australia (Morton, 2000) and Ireland (Buckley et al., 2003). If the factors underpinning this association can be understood, substantial benefits may exist for the Australian dairy industry, due not only to improved reproductive performance but also to increased milk value, as each kilogram of milk protein is more than twice as valuable as each kilogram of milk fat under many milk payment systems in Australia (Downey and Doyle, 2007).

Differences in the way that cows partition energy in early lactation and the extent of postpartum NEB, when energy demands for maintenance plus lactation exceed energy intake, provide one possible explanation for the association. Postpartum NEB can reduce MPC due to a shortage of glucose for milk protein synthesis in the mammary gland (de Vries and Veerkamp, 2000). Negative energy balance is, in turn, associated with poor reproductive performance (Butler, 2003; Reist et al., 2003). However, Fahey et al. (2008) demonstrated a positive association between the reproductive performance of nonlactating heifers and their subsequent MPC in their first lactation. These animals were bred when they were around 15 mo of age, which shows that the biological determinants underpinning the association are not restricted to lactation-specific factors.

The objective of this experiment was to compare milk production variables, physical characteristics, and blood plasma concentrations of selected metabolites and hormones in primiparous Holstein-Friesian cows with either high or low MPC to gain an understanding of possible mechanisms behind the association. The hypotheses tested were (1) that the low-MPC cows would preferentially partition nutrients and energy toward milk synthesis in early lactation at the expense of BCS compared with their high MPC contemporaries, and that these partitioning differences would be reflected in plasma metabolite and hormone concentrations; (2) that the cows with high MPC would maintain a greater BCS during early lactation compared with the lowMPC cows; and (3) that milk energy output in early lactation would be greater for the low-MPC cows.

\section{MATERIALS AND METHODS}

\section{Cows and Management}

Data were collected from 85 primiparous HolsteinFriesian cows at the research farm of the Depart- ment of Economic Development, Jobs, Transport and Resources at Ellinbank, Victoria $\left(38^{\circ} 14^{\prime} \mathrm{S}, 145^{\circ} 56^{\prime} \mathrm{E}\right)$. Cows had been reared as a single group from $12 \mathrm{wk}$ of age and calved for the first time in July, August, and September 2013 (average calving date of August 1) when they were aged between 1.8 and $2.1 \mathrm{yr}$. After calving, all enrolled cows were managed as a single herd for the entire lactation and received a common nutritional and management regimen. Their pasture-based diet consisted mainly of grazed perennial ryegrass pasture, with pasture silage and hay fed in the paddock in summer and autumn. They were milked twice daily through a common dairy at approximately 0600 and $1500 \mathrm{~h}$, where they received an average of $3.7 \mathrm{~kg}$ of $\mathrm{DM} /$ cow per day of grain (wheat and canola meal). All experimental procedures were approved by the Department of Economic Development, Jobs, Transport and Resources Agricultural Research and Extension Animal Ethics Committee.

\section{Breeding Program}

The seasonally concentrated breeding program during early lactation commenced on October 15, 2013, and initially involved the use of AI for $6 \mathrm{wk}$, after which time Holstein-Friesian bulls were introduced into the herd for a further 6 wk. Thirty cows were diagnosed as anestrus in late October, and were treated with a controlled internal drug-releasing device (Pfizer Australia, West Ryde, NSW, Australia) inserted vaginally for 8 d concurrently, with an injection of $\mathrm{GnRH}$ at device insertion (1 mL of GONAbreed, Parnell Technologies, Australia) and then an injection of $\mathrm{PGF}_{2 \alpha}(5 \mathrm{~mL}$ of Lutalyse, Pfizer Australia) at removal, followed by AI at observed heat. Conception dates were identified using rectal ultrasound pregnancy testing conducted in late January 2014.

\section{Measurements and Analyses}

Milk yield was measured at each milking using a DeLaval Alpro milk metering system (DeLaval International, Tumba, Sweden), whereas a composite milk sample (p.m. and a.m.) was taken weekly using in-line milk meters from calving until November, and then fortnightly until each cow had reached 120 DIM (the final sample for the last cow was taken in January 2014). Samples were tested for concentrations of protein, fat, and lactose using a near-infrared milk analyzer (Model 2000, Bentley Instruments, Chaska, MN), which allowed the calculation of yields of each component. Daily milk energy output and concentration for each cow was estimated by assigning protein, fat, and lactose net en- 
ergy contents of $24.1,38.3$, and $16.5 \mathrm{~kJ} / \mathrm{g}$, respectively (Sjaunja et al., 1990), and considering daily milk yield.

Blood samples were collected weekly from 2 wk before calving until November and then at monthly intervals until the end of early lactation (120 DIM for each cow or January 2014). At each sampling, two 10-mL blood samples were collected via coccygeal venipuncture into Vacutainers, one containing powdered lithium heparin and the other potassium EDTA (BD Vacutainer System, Belliver Industrial Estate, Plymouth, UK). Samples were gently inverted and stored on ice until they were processed (within 60 min of collection). Blood samples were centrifuged at $1,800 \times g$ for $10 \mathrm{~min}$ at $4^{\circ} \mathrm{C}$, after which the blood plasma was aspirated into two $5-\mathrm{mL}$ sample tubes and stored at $-18^{\circ} \mathrm{C}$ before analysis.

Metabolite assays (glucose, fatty acids, urea, BHB) were conducted using an Olympus AU400 Clinical Chemical Analyzer (Beckman Coulter Inc., Brea, $\mathrm{CA})$. Plasma glucose concentrations $(\mathrm{mmol} / \mathrm{L})$ were measured using a Beckman Coulter/Olympus Glucose Reagent Kit (Department of Agriculture and Food, Western Australia Animal Health Laboratories, South Perth, Western Australia, Australia). Concentrations of plasma fatty acids $(\mathrm{mmol} / \mathrm{L})$ were measured using the commercially available Wako fatty acids-C Reagent Kit (Wako Chemicals USA, Richmond, VA). The concentrations of plasma urea $(\mathrm{mmol} / \mathrm{L})$ were measured using a Beckman Coulter/Olympus Reagent Kit (Department of Agriculture and Food, Western Australia Animal Health Laboratories), and plasma BHB (mmol/L) using a Randox Ranbut Reagent Kit (Department of Agriculture and Food, Western Australia Animal Health Laboratories). The samples were assayed in duplicate. Intra- and interassay coefficients of variation were 1.31 and $1.51 \%$ for glucose; 3.87 and $4.28 \%$ for fatty acids; 3.87 and $3.83 \%$ for urea; and 2.31 and $2.29 \%$ for BHB, respectively. Hormone concentrations (insulin, IGF-1, leptin, somatotropin) were assayed in duplicate by determining the activity of the precipitate on a gamma counter (Packard Cobra-II Gamma Counter, Perkin Elmer, Waltham, MA). Plasma insulin concentrations $(\mu \mathrm{U} / \mathrm{mL})$ were assayed using a double-antibody RIA described by Tindal et al. (1978). The concentrations of plasma IGF-1 $(\mathrm{ng} / \mathrm{mL})$ were measured by the chloramine-T RIA method, as described by Gluckman et al. (1983). Plasma leptin concentrations $(\mathrm{ng} / \mathrm{mL})$ were measured using a double-antibody RIA (Blache et al., 2000), and plasma somatotropin concentration $(\mathrm{ng} / \mathrm{mL})$ was assayed using a double-antibody RIA described by Downing et al. (1995). Intra- and interassay coefficients of variation were $<4.7$ and $<7.1 \%$ for insulin; $<8.2$ and $<4.9 \%$ for IGF- $1 ;<6.2$ and $<8.5 \%$ for leptin; and $<6.1$ and $<6.72 \%$ for somatotropin, respectively.
The BCS of each cow was assessed at weekly intervals from 2 wk before calving until November, and then monthly for the remainder of early lactation (120 DIM for each cow or January 2014), using the 8-point scale of Earle (1976).

\section{Statistical Analysis}

Each cow was retrospectively categorized into a quartile based on their average MPC during the first $120 \mathrm{~d}$ of lactation, similar to the lactation period used previously (Morton, 2000). The 21 cows within the highest (3.22 to $3.40 \%)$ and the 21 cows within the lowest (2.87 to $3.00 \%)$ MPC quartiles are henceforth referred to as the high and low MPC quartile groups, respectively. The results presented demonstrate differences between only these 2 groups. Cows' early lactation data were analyzed excluding the first week postpartum to ensure that the results pertained to noncolostrum milk. Prepartum analyses of blood plasma metabolites and hormones and cow body condition were also undertaken. Analyses were conducted using GenStat 17 (VSN International Ltd., Hemel Hempstead, UK) statistical software.

The data set for statistical analysis comprised 5 periods, including a prepartum period of 2 wk duration (period 0) and 4 postpartum periods each of $4 \mathrm{wk}$ in duration (periods 1 to 4 ), beginning at $7 \mathrm{~d}$ postpartum and ending at 120 DIM. For each of the high- and lowMPC cows, within each period all available temporal data were averaged for each variable. Weighted milk composition based on milk yield was calculated for each week, and then averaged within each period. Thus, this data set comprised 42 cows with up to 5 periods for each variable, subject to data availability (for example, no milk production data were available for period 0 ). These data were analyzed by repeated-measures ANOVA with a blocking structure cow split for period, and fixed effects for quartile group (high or low) split by period. For simplicity, main effects were reported even where significant quartile by period interactions were detected. One-way ANOVA were conducted to analyze the differences in the pre-partum variables between the high- and low-MPC cows (period 0), having the quartile group as the treatment structure and cow as the unit.

The ANOVA assumptions of normality and constant variance were checked graphically using plots of residuals versus fitted values, histograms, and normal quantile plots. Log-transformations were applied where necessary to meet these distributional assumptions.

Reproductive performance data were analyzed by 2 methods. Differences between the high- and low-MPC cows for days from calving until the mating start date 
(MSD; the start of the seasonal breeding period), days from calving until first insemination, days from the MSD to first insemination and conception, and the number of days open were assessed using survival analysis. In these analyses, right-censored intervals to first AI and to conception were calculated as the last date of the AI period and to the last date that the bulls ran with the herd, respectively. After these dates, no more AI and conceptions, respectively, could occur. Contingency tables formulating a Pearson Chi-squared value were employed to assess differences in 3-wk submission rate, first insemination conception rate, and 6-wk in-calf rate, measures used previously in Australia (Morton, 2010). Calving dates were compared using one-way ANOVA with MPC quartile as the treatment and cow as the unit.

\section{RESULTS}

\section{Milk Yield, Composition, and Energy Yield}

Average milk protein concentration for cows in the high MPC quartile was $3.27 \%$ (range $=3.22$ to $3.40 \%$ ) during early lactation, whereas cows in the low MPC quartile averaged $2.94 \%$ (range $=2.87$ to $3.00 \%$ ). Mean daily milk yield was greater for the low- than highMPC cows (22.8 vs. 20.0 L from 8 to 120 DIM), with this difference being greatest in period $1(4.9 \mathrm{~L})$ and then declining to $2.1 \mathrm{~L}$ in period 4 (Table 1). Average milk fat concentrations were greater for the highcompared with the low-MPC cows (4.14 vs. $3.74 \%$ ), as were milk lactose concentrations (5.19 vs. $5.13 \%$; Table 1). We found no difference between the MPC quartiles for average milk protein and fat yields. Average milk lactose yields in early lactation for the low- and highMPC cows were 1.17 and $1.04 \mathrm{~kg}$, respectively $(P=$ 0.015 ; Table 1). Whereas we observed no statistically significant difference in milk energy yield between the high- and low-MPC quartiles (66.06 vs. $67.85 \mathrm{MJ} / \mathrm{cow}$, respectively), we did note a difference in milk energy concentration (3.23 vs. $2.99 \mathrm{MJ} / \mathrm{L}$ for high vs. low, respectively; $P<0.001)$.

\section{Nutrient Partitioning}

Blood plasma metabolite and hormone concentrations were analyzed pre- and postpartum for the high- and low-MPC cows. Only the difference in the prepartum concentrations of leptin between the cows in the $2 \mathrm{MPC}$ quartiles approached statistical significance $(0.96$ vs. $0.85 \mathrm{ng} / \mathrm{mL}$ for the high and low cows, respectively; $P=0.051$; Table 2). Differences between MPC quartiles postpartum are summarized below as mean for the high- minus low-MPC cows, expressed as absolute percentages of mean for the low-MPC cows. Postpartum (periods 1 to 4 inclusive), the high-MPC cows had $2.7 \%$ higher mean plasma concentrations of glucose $(P=0.03)$, higher plasma insulin $(20.6 \%$; $P=$ $0.002)$, IGF-1 (42.2\%; $P<0.001)$, and leptin $(11.5 \%$; $P=0.006$ ) than the low-MPC cows (Table 3). These concentrations were consistently higher in the highMPC cows through the 4 periods from 8 to 120 DIM. In particular, IGF-1 concentrations were higher for the high-MPC cows, and the difference in concentration between the high- and low-MPC cows increased as early lactation progressed, with the greatest difference occurring in period $4(18.24 \mathrm{vs} 11.7 \mathrm{ng} / \mathrm{mL}$, respectively; Table 3). Mean plasma concentrations of fatty acids, urea, BHB, and somatotropin were numerically lower in cows in the high MPC quartile $(6.3,6.3,6.1$, and $18.8 \%$, respectively), but we found no statistically significant differences ( $P$-values from 0.126 to 0.254 ; Table 3).

\section{BCS}

Average prepartum BCS was not different for cows in the high and low MPC quartiles (4.63 vs. 4.60 units) and both had similar declines to period 1 ( -0.55 vs -0.51 ). Overall, both quartiles lost $>0.5$ units of body condition (i.e., mean of BCS changes of all cows in each quartile were $>0.5$ units) following parturition $(P<0.001)$, with a trend to significance for the highMPC cows to lose less body condition compared with low-MPC cows (mean BCS changes 0.58 vs. 0.67 units, respectively; $P=0.051$ ). Consistent with this, the high-MPC cows maintained a higher average BCS in comparison to the low-MPC cows up to 120 DIM (4.11 vs. 4.03 units; $P=0.049$ ).

\section{Reproductive Performance}

Reproductive performance at 15 mo of age was assessed by comparing the resulting calving dates and calving to MSD intervals; other results presented pertain to the reproductive performance of the cows after their first calving. Cows with high MPC had significantly earlier calving dates compared with the low-MPC cows (mean calving date July 26 vs. August $7 ; P=0.021)$. This resulted in a greater number of days from calving until MSD for the high-MPC cows (78.1 vs. $67.1 ; P=0.024)$. The interval from calving to first insemination was also greater ( 83.1 vs. $73.6 ; P=0.046$ ) for the high-MPC cows.

We found no difference in the intervals from MSD to first insemination between high- and low-MPC cows (6.3 and $6.5 \mathrm{~d}$, respectively; $P=0.995$ ), nor in the intervals from the MSD to conception (30.1 and $46.2 \mathrm{~d}$, 
MILK PROTEIN CONCENTRATION AND ENERGY PARTITIONING

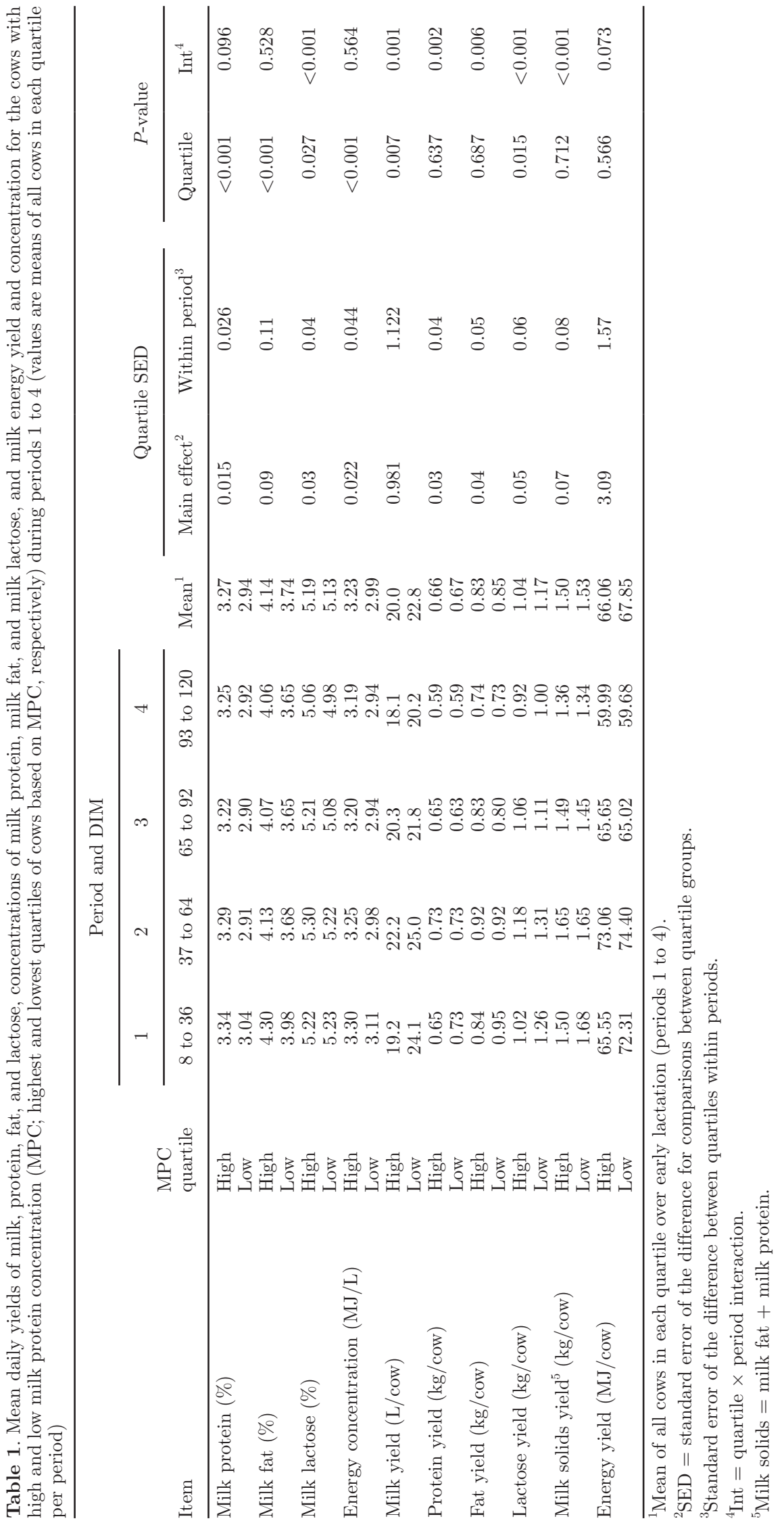


Table 2. Mean concentrations of glucose, fatty acids, urea, BHB, insulin, IGF-1, leptin, and somatotropin prepartum for the cows with high and low milk protein concentration (MPC) in the ensuing lactation (highest and lowest quartiles of cows based on MPC, respectively; values are means of all cows in each quartile per period)

\begin{tabular}{|c|c|c|c|c|}
\hline Nutrient & Quartile & Average & $\mathrm{SED}^{1}$ & $P$-value \\
\hline Glucose (mmol/L) & High & $\begin{array}{l}3.28 \\
3.32\end{array}$ & 0.827 & 0.642 \\
\hline Fatty acids (mmol/L) & $\begin{array}{l}\text { High } \\
\text { Low }\end{array}$ & $\begin{array}{l}0.02 \\
1.23 \\
1.03\end{array}$ & 0.126 & 0.118 \\
\hline Urea $(\mathrm{mmol} / \mathrm{L})$ & $\begin{array}{l}\text { High } \\
\text { Low }\end{array}$ & $\begin{array}{l}5.90 \\
5.86\end{array}$ & 0.276 & 0.877 \\
\hline $\mathrm{BHB}(\mathrm{mmol} / \mathrm{L})$ & $\begin{array}{l}\text { High } \\
\text { Low }\end{array}$ & $\begin{array}{l}1.21 \\
1.23\end{array}$ & 0.134 & 0.888 \\
\hline Insulin $(\mu \mathrm{U} / \mathrm{mL})$ & $\begin{array}{l}\text { High } \\
\text { Low }\end{array}$ & $\begin{array}{l}3.36 \\
3.29\end{array}$ & 0.404 & 0.862 \\
\hline IGF-1 (ng/mL) & $\begin{array}{l}\text { High } \\
\text { Low }\end{array}$ & $\begin{array}{l}20.96 \\
19.98\end{array}$ & 3.20 & 0.760 \\
\hline Leptin $(\mathrm{ng} / \mathrm{mL})$ & $\begin{array}{l}\text { High } \\
\text { Low }\end{array}$ & $\begin{array}{l}0.96 \\
0.85\end{array}$ & 0.051 & 0.051 \\
\hline Somatotropin $(\mathrm{ng} / \mathrm{mL})$ & $\begin{array}{l}\text { High } \\
\text { Low }\end{array}$ & $\begin{array}{l}3.40 \\
2.97\end{array}$ & 0.660 & 0.516 \\
\hline
\end{tabular}

${ }^{1} \mathrm{SED}=$ standard error of the difference.

respectively; $P=0.439)$. This resulted in intervals from calving to conception of 106.9 and $113.3 \mathrm{~d}(P=0.426)$ for the high- and low-MPC cows. Meanwhile, the first insemination conception rates were 47.6 and $52.4 \%$ ( $P$ $=0.748$ ) for the high- and low-MPC cows, respectively; the 3 -wk submission rates were 95.2 and $90.5 \%(P=$ $0.528)$ and the 6 -wk in-calf rates were 71.4 and $61.9 \%$ $(P=0.498)$ for the high- and low-MPC cows.

Following initial analyses, all physiological, endocrinological, and reproductive performance interval data were analyzed adjusting variables for calving date. The results indicated no important influence of calving date on differences in these variables between the high- and low-MPC cows.

\section{DISCUSSION}

The positive association between MPC and dairy cow fertility has been demonstrated in several studies globally and is well accepted. Cows with higher MPC have shorter intervals from calving to first service, calving to conception (Miettinen and Setälä, 1993), and calving to first estrus (McGowan et al., 1996), but higher rates of submission (Morton, 2000, 2010; Xu and Burton, 2003), conception (McDougall, 2003; Yang et al., 2009), and pregnancy (Buckley et al., 2003; Xu and Burton, 2003; Yang et al., 2009) than cows with low MPC in seasonally calving herds. If the factors underpinning these associations could be elucidated, potential may exist for the relationship to be used to predict and manage at-risk cows or to select cows with higher fertility. Previous research has focused on cows managed under similar conditions (Xu and Burton,
1996; Morton, 2000; Buckley et al., 2003) and other studies have also retrospectively separated cows into MPC quartiles to determine differences in reproductive performance (Fahey et al., 2008). However, despite the potential benefits, the current experiment represents the first attempt to understand the physiological and endocrinological differences between Holstein-Friesian cows with high and low MPC in a seasonally calving, pasture-based herd.

One possible explanation for the association is differences in the ways that cows in the high and low MPC groups partitioned energy during early lactation. When milk yield reaches a peak, some 8 to 9 wk after parturition, energy demands of lactation may be greater than the amount of energy that can be obtained from the diet (NRC, 2001). Cows will mobilize their body tissue reserves to meet the energy requirements for milk production during early lactation (de Vries and Veerkamp, 2000); this is observed quite significantly in cows fed a pasture-based diet in comparison with cows fed a TMR diet. Greater NEB is associated with reduced fertility and reduced MPC (de Vries and Veerkamp, 2000) due to a higher proportion of available AA being used for gluconeogenesis and a reduction in their availability for milk protein synthesis (Auldist et al., 2000). The results of the current study are consistent with differences in the way that the high- and low-MPC cows were partitioning energy in early lactation and that the extent of NEB was greater in the low-MPC cows. A shift of homeorhetic controls occurs during early lactation in order for milk production to be maximized from a combination of ingested nutrients and mobilization of available body tissue reserves (Bauman, 2000). The 2 


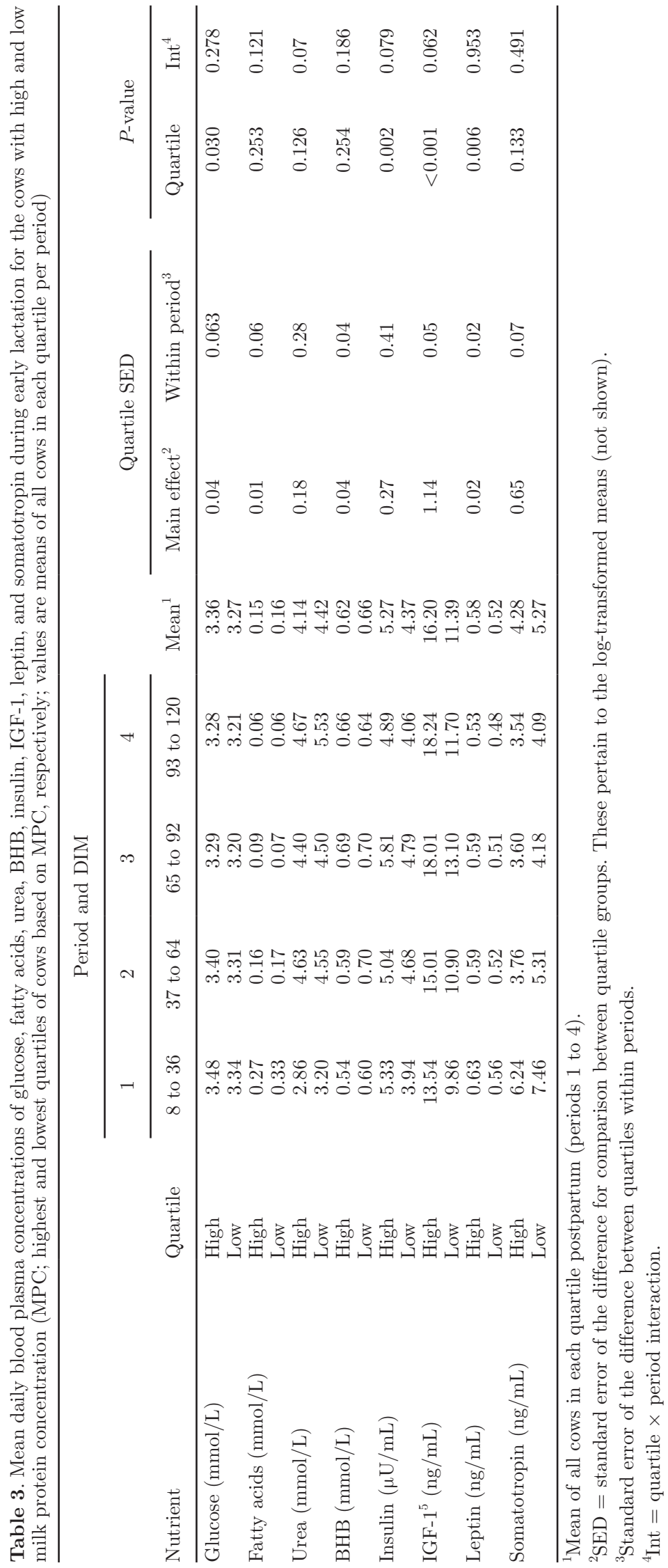


quartiles of cows (i.e., the high and low MPC quartiles) coordinated their metabolisms differently, indicated by the physiological differences that were detected. For example, the high-MPC cows had greater postpartum blood plasma concentrations of glucose, insulin, IGF-1 and leptin, a lower daily milk yield, and maintained a greater $\mathrm{BCS}$ compared with the low-MPC cows. The homeorhetic controls in these high-MPC cows were more favorable for improved energy balance; thus, the differences in metabolite and hormone concentrations between the 2 MPC quartiles support our first hypothesis.

Insulin-like growth factor-1 is recognized as a useful indicator of NEB (Lucy et al., 2009). Our results show that the high-MPC cows had consistently greater concentrations of plasma IGF-1, with differences between the quartiles increasing as early lactation progressed (differences between MPC quartiles of $35.9 \%$ in period 1 increased to $55.8 \%$ in period 4; Table 3). This is indicative of the high-MPC cows having a more positive energy balance than the low-MPC cows.

Glucose is preferentially partitioned to the mammary gland for the synthesis of lactose in early lactation at the expense of uptake by peripheral tissues; however, a high plasma insulin concentration promotes the uptake of glucose by peripheral tissues such as muscle (Bonczek et al., 1988; Beever et al., 2001; Lucy, 2006). Greater plasma insulin concentrations in the high-MPC cows may have allowed maintenance of a greater BCS due to an increased glucose uptake by peripheral tissues. This is consistent with the fact that these cows also produced less milk in early lactation. Plasma leptin concentration can provide an indication of cow body condition, as its secretion is proportional to the amount of adipose tissue present (Hart et al., 1979; Reist et al., 2003). Thus, the greater BCS in the high-MPC cows may be associated with their greater plasma leptin concentrations. Our data showed that the high-MPC cows experienced a less severe NEB than their low-MPC herdmates, consistent with their greater BCS.

We found no significant differences between the MPC groups for prepartum metabolite and hormone concentrations with the exception of leptin, where numerical differences between the 2 MPC quartiles approached statistical significance $(P=0.051$; Table 2$)$. We also noted no differences in BCS between the high- and low-MPC cows before parturition. These results indicate that the high- and low-MPC cows were not under metabolic stress or exposed to NEB before calving. However, blood plasma fatty acid concentrations were 4 times greater prepartum compared with immediately postpartum. It is unusual for plasma fatty acid concentrations to be greater precalving, even in primiparous cows (Wathes et al., 2007). The elevated plasma fatty acid concentrations observed precalving in this experiment may be related to a stress response at sampling time as a result of lower acclimation to human interaction before joining the research herd around the time of calving. Overall, the results indicate that differences in concentrations of blood plasma metabolites and hormones, milk yield, and BCS measured postpartum were not related to pre-existing differences prepartum. Nor were they confounded by prepartum management, as both MPC groups were managed collectively. Therefore, differences in anatomical, physiological, and endocrinological measures postpartum between the high- and low-MPC cows were the result of differences in metabolic and homeorhetic controls during lactation.

The possibility that the low-MPC cows endured a greater extent of NEB is consistent with their lower BCS during early lactation. Both MPC groups had the same BCS before parturition, and although a loss of body condition occurred for cows in both groups, the loss in the low-MPC cows was greater, likely reflecting greater or more prolonged NEB (Pryce et al., 2001). This was associated with increased milk yields for the low-MPC cows, and reduced concentrations of plasma leptin. Maintenance of a greater BCS for the high-MPC cows supports our second hypothesis. The low-MPC cows, through differences in nutrient partitioning, may have placed a greater emphasis on milk production in comparison to the high-MPC cows, while placing a lower priority on maintenance of body condition. Further research is required to elucidate this possible difference.

Average daily milk energy yield was not significantly different between the high and low MPC quartiles, nor were significant differences found in daily yields of milk fat or protein between the high- and low-MPC cows. This occurred because the significantly greater milk energy concentration in the high compared with the lowMPC cows compensated for lower milk yields; thus, our third hypothesis was rejected. The lack of significant difference in milk energy output between the 2 MPC quartiles shows that, although some of the association between MPC and fertility may be related to differences in the way cows partition energy between milk and body tissue, other important factors remain undefined. This is consistent with the report of Fahey et al. (2008), who stated that the capacity of primiparous heifers to conceive when they were yet to commence lactation was significantly associated with their MPC in their subsequent lactation; hence, the associated biological determinants are not restricted to lactation-specific mechanisms, such as postpartum energy balance, and the effect that this has on the metabolism of the cow (Fahey and Macmillan, 2003a). It is also consistent 
with Morton et al. (2016) that the association between MPC and dairy cow fertility persists at all stages of lactation, including mid and late lactation, when cows have typically regained a positive energy status.

Despite the small sample size, we noted significant differences between the high and low MPC quartiles for at least 2 indicators of reproductive performance. The high-MPC cows had a greater number of days until MSD. This was attributed to their significantly earlier calving date, reflecting their reproductive performance when 15 mo of age, as previously reported (Fahey et al., 2003b). This is advantageous, particularly for seasonally calving herds, as a greater number of days between calving and the herd MSD allows sufficient time for a cow to recommence ovarian cyclicity before mating, positively influencing her likelihood for submission for AI and conception within the first $6 \mathrm{wk}$ of mating. Seasonal-calving cows with an earlier calving date are more likely to conceive earlier in the breeding season and remain early-calving cows in the following lactation because a greater number of days exist between calving and first insemination, increasing the likelihood of cycling more than once before mating and, hence, positively influencing conception rate (Butler and Smith, 1989). The interval from first insemination to conception can be influenced by the earlier calving date, due to the increased likelihood of earlier calving cows conceiving to first insemination. The lower interval from first insemination to conception for the high-MPC cows would likely result in an earlier calving date (15.9 d earlier) for these cows in the second lactation. A shorter interval from first insemination to conception is beneficial for dairy farmers with seasonally calving herds, and can influence the cow's ability to get back in calf later in her lifetime. This is reflected in the greater portion of the high-MPC cows conceiving compared with the low-MPC cows in our experiment.

Reproductive performance can also be linked to concentrations of plasma hormones, with higher concentrations of IGF-1 associated with shorter intervals to first ovulation in pasture-based systems (Obese et al., 2011) and higher insulin concentrations reported to be positively associated with the recommencement of cycling (Butler et al., 2004). Whereas cycling dates before the herd MSD were not recorded, higher concentrations of IGF-1 and insulin were observed in the high-MPC cows; therefore, it is highly likely that these cows had recommenced ovarian cyclicity before the MSD. Thus, the reproductive performance results from our experiment were consistent with the results of previous studies, even though there were low numbers of cows in each quartile and the objective was not to prove the relationship between MPC and reproductive performance.

\section{CONCLUSIONS}

This study has shown that the high-MPC cows had higher blood plasma concentrations of glucose, insulin, IGF-1, and leptin, higher average BCS in early lactation, and a lower early-lactation milk yield than lowMPC cows. Collectively these observations suggest that the low-MPC cows may have partitioned more energy to milk production at the expense of body tissue than high-MPC cows. Nevertheless, estimates of the comparative amounts of milk energy produced by the high- and low-MPC cows were not supportive of greater energy partitioning to milk synthesis by the low-MPC cows. We concluded that, although differences in energy partitioning in early lactation may partially underpin the positive association between MPC and fertility in dairy cattle, other important factors are involved. Further research is required to fully elucidate these mechanisms so that the potential benefits of the association for the dairy industry can be used.

\section{ACKNOWLEDGMENTS}

The authors are grateful to J. Garner, M. Wright, C. MacLeod, S. Ziero, D. Mapleson, L. Dorling, G. Morris, and staff at the Department of Economic Development, Jobs, Transport and Resources research farm at Ellinbank for their technical assistance with sampling procedures and cow husbandry. This research was funded by the Department of Economic Development, Jobs, Transport and Resources.

\section{REFERENCES}

Auldist, M. J., G. O’Brien, D. Cole, K. L. Macmillan, and C. Grainger. 2007. Effects of varying lactation length on milk production capacity of cows in pasture-based dairying systems. J. Dairy Sci. 90:3234-3241.

Auldist, M. J., N. A. Thomson, T. R. Mackle, J. P. Hill, and C. G. Prosser. 2000. Effects of pasture allowance on the yield and composition of milk from cows of different $\beta$-lactoglobulin phenotypes. J. Dairy Sci. 83:2069-2074.

Bauman, D. E. 2000. Regulation of nutrient partitioning during lactation: homeostasis and homeorhesis revisited. Pages 311-328 in Ruminant Physiology: Digestion, Metabolism, Growth and Reproduction. CAB International, New York, NY.

Beever, D. E., J. D. Sutton, and C. K. Reynolds. 2001. Increasing the protein content of cow's milk. Aust. J. Dairy Technol. 56:138-149.

Blache, D., R. Tellam, L. M. Chagas, M. A. Blackberry, P. V. Vercoe, and G. B. Martin. 2000. Level of nutrition affects leptin concentrations in plasma and cerebrospinal fluid in sheep. J. Endocrinol. 165:625-637

Bonczek, R. R., C. W. Young, J. E. Wheaton, and K. P. Miller. 1988. Responses of somatotropin, insulin, prolactin, and thyroxine to selection for milk yield in Holsteins. J. Dairy Sci. 71:2470-2479.

Buckley, F., K. O'Sullivan, C. C. Metges, R. D. Evans, and P. Dillon. 2003. Relationships among milk yield, body condition, cow weight, and reproduction in spring-calved Holstein-Friesians. J. Dairy Sci. $86: 2308-2319$ 
Butler, S. T., S. H. Pelton, and W. R. Butler. 2004. Insulin increases $17 \beta$-estradiol production by the dominant follicle of the first postpartum follicle wave in dairy cows. Reproduction 127:537-545.

Butler, W. R. 2003. Energy balance relationships with follicular development, ovulation and fertility in postpartum dairy cows. Livest. Prod. Sci. 83:211-218.

Butler, W. R., and R. D. Smith. 1989. Interrelationships between energy balance and postpartum reproductive function in dairy cattle. J. Dairy Sci. 72:767-783.

de Vries, M. J., and R. F. Veerkamp. 2000. Energy balance of dairy cattle in relation to milk production variables and fertility. J. Dairy Sci. 83:62-69.

Downey, L., and P. T. Doyle. 2007. Cow nutrition and dairy product manufacture-Implications of seasonal pasture-based milk production systems. Aust. J. Dairy Technol. 62:3-11.

Downing, J. A., J. Joss, P. Connell, and R. J. Scaramuzzi. 1995. Ovulation rate and the concentrations of gonadotrophic and metabolic hormones in ewes fed lupin grain. J. Reprod. Fertil. 103:137-145.

Earle, D. F. 1976. A guide to scoring dairy cow condition. J. Agric. Vic. $74: 228-231$

Fahey, J., and K. L. Macmillan. 2003a. Relationship between milk protein percentage and reproductive performance in Australian dairy cows. Proc. N.Z. Soc. Anim. Prod. 63:82-86.

Fahey, J., J. M. Morton, and K. L. Macmillan. 2003b. Associations between milk protein percentage and reproductive performance in Holstein-Friesian cows in seasonal-calving dairy herds. Proc. Adv. Anim. Breed Gen. 15:68-71.

Fahey, J., J. M. Morton, and K. L. Macmillan. 2008. Associations between milk protein concentration and preceding reproductive performance in Holstein-Friesian heifers and cows in Australia. Proc. N.Z. Soc. Anim. Prod. 68:69-72.

Gluckman, P. D., J. J. Johnson-Barrett, J. H. Butler, B. W. Edgar, and T. R. Gunn. 1983. Studies in insulin-like growth factor-I and -II by specific radioligand assays in umbilical cord blood. Clin. Endocrinol. (Oxf.) 19:405-413.

Hart, I. C.. J. A. Bines, and S. V. Morant. 1979. Endocrine control of energy metabolism in the cow: correlations of hormones and metabolites in high and low yielding cows for stages of lactation. J. Dairy Sci. 62:270-277.

Lucy, M. 2006. Mechanisms linking growth hormone, insulin and reproduction: Lessons from the postpartum dairy cow. Cattle Pract. $14: 23-27$

Lucy, M. C., G. A. Verkerk, B. E. Whyte, K. A. Macdonald, L. Burton, R. T. Cursons, J. R. Roche, and C. W. Holmes. 2009. Somatotropic axis components and nutrient partitioning in genetically diverse dairy cows managed under different feed allowances in a pasture system. J. Dairy Sci. 92:526-539.

McDougall, S. 2003. Resynchrony of previously anoestrous cows and treatment of cows not detected in oestrus that had a palpable corpus luteum with prostaglandin $\mathrm{F}_{2 \alpha}$. N. Z. Vet. J. 51:117-124.

McGowan, M. R., R. F. Veerkamp, and L. Anderson. 1996. Effects of genotype and feeding system on the reproductive performance of dairy cattle. Livest. Prod. Sci. 46:33-40.

Miettinen, P. V. A., and J. J. Setälä. 1993. Relationships between subclinical ketosis, milk production and fertility in Finnish dairy cattle. Prev. Vet. Med. 17:1-8.

Morton, J. 2000. The InCalf Project-Some risk factors for reproductive performance in Australian dairy herds. Pages 43-62 in
Proc. Australian and New Zealand Combined Dairy Veterinarians' Conference, Port Vila, Vanuatu. Veterinary Continuing Education, Palmerston North, New Zealand.

Morton, J. 2011. InCalf Fertility Data Project 2011. Dairy Australia, Melbourne, Australia.

Morton, J. M. 2010. Interrelationships between herd-level reproductive performance measures based on intervals from initiation of the breeding program in year-round and seasonal calving dairy herds. J. Dairy Sci. 93:901-910.

Morton, J. M., M. J. Auldist, M. L. Douglas, and K. L. Macmillan. 2016. Associations between milk protein concentration at various stages of lactation and reproductive performance in dairy cows. J. Dairy Sci. 99:10044-10056. http://dx.doi.org/10.3168/jds.201611276.

NRC. 2001. Nutrient Requirements of Dairy Cattle. 7th rev. ed. Natl. Acad. Press, Washington, DC.

Obese, F. Y., T. E. Stirling, R. C. Stockdale, K. L. Macmillan, A R. Egan, and S. Humphrys. 2011. Effect of concentrate supplementation during early lactation on plasma IGF-I concentrations and reproductive performance of dairy cows. S. Afr. J. Anim. Sci. 41:360-367.

Pryce, J. E., M. P. Coffey, and G. Simm. 2001. The relationship between body condition score and reproductive performance. J. Dairy Sci. 84:1508-1515.

Reist, M., D. Erdin, D. von Euw, K. Tschuemperlin, H. Leuenberger, C. Delavaud, Y. Chilliard, H. M. Hammon, N. Kuenzi, and J. W. Blum. 2003. Concentrate feeding strategy in lactating dairy cows: metabolic and endocrine changes with emphasis on leptin. J. Dairy Sci. 86:1690-1706.

Sjaunja, L. O., L. Baevre, L. Junkkarinen, J. Pedersen, and J. Setala. 1990. Measurement of the total energy contents of cow's milk and the energy value of milk fat and milk protein. Pages $152-155$ in Proc. 27th Biennial Session of the International Committee for Animal Recording, Paris, France. Centre for Agricultural Publishing and Documentation, the Netherlands.

Tindal, J. S., G. S. Knaggs, S. Hartwig, and L. A. Blake. 1978. Release of growth hormone in lactating and non-lactating goats in relation to behaviour, stages of sleep, electroencephalograms, environmental stimuli and levels of prolactin, insulin, glucose and free fatty acids in the circulation. J. Endocrinol. 76:333-346.

Wathes, D. C., Z. Cheng, N. Bourne, V. J. Taylor, M. P. Coffey, and S. Brotherstone. 2007. Differences between primiparous and multiparous dairy cows in the inter-relationships between metabolic traits, milk yield and body condition score in the periparturient period. Domest. Anim. Endocrinol. 33:203-225.

Xu, Z. Z., and L. J. Burton. 1996. Reproductive efficiency in lactating dairy cows. Proc. N.Z. Soc. Anim. Prod. 56:34-37.

Xu, Z. Z., and L. J. Burton. 2003. Reproductive Performance of Dairy Cows in New Zealand. Final Report of the Fertility Monitoring Group. Livestock Improvement Corporation, Hamilton, New Zealand.

Yang, L., N. Lopez-Villalobos, D. P. Berry, and T. Parkinson. 2009 Phenotypic relationship between milk protein percentage and reproductive performance in three strains of Holstein Friesian cows in Ireland. Proc. N.Z. Soc. Anim. Prod. 70:29-32. 